\title{
Research on Ecosystem Construction of Cross- Border E-Commerce Talent Cultivation
}

\author{
Liang Zhao \\ School of Management Engineering \\ Zhengzhou University \\ Zhengzhou China \\ E-mail: 1633594088@qq.com
}

\author{
Gaoke $\mathrm{Yu}^{*}$ \\ School of Management Engineering \\ Zhengzhou University \\ Zhengzhou China \\ E-mail: 1512451398@qq.com
}

\begin{abstract}
In order to solve the problems of inadequate implementation of responsibilities and the irrational mechanism of the talent cultivation parties of cross-border e-commerce, the research team investigated the talent cultivation model of Zhengzhou cross-border e-commerce. It was found that the cross-border e-commerce talent cultivation model lacked a feedback adjustment mechanism, which led to the lack of talent cultivation for cross-border e-commerce by parties including schools and enterprises. Therefore, based on the feedback adjustment of the ecosystem, this paper builds a market-oriented multi-faceted talent cultivation ecosystem, which makes up for the lack of research on the cultivation of cross-border ecommerce talents in the past. It provides a reference for the construction of diverse and multi-level talent cultivation ecology.
\end{abstract}

Keywords-Cross-Border E-Commerce; Talent Cultivation; Ecosystem; Feedback Adjustment

\section{INTRODUCTION}

In October 2018, in response to the current increasingly fierce competition among global cross-border e-commerce merchants, Amazon launched the "Amazon Global Opening 101 • Times Youth Program" training program, which specifically cultivates cross-border for China based on the status of cross-border e-commerce development in China Ecommerce talent. In June 2019, "cross-border e-commerce" is one of the newly added specialties in the supplementary specialties of the "Professional Catalog of Secondary Vocational Schools" announced by the Ministry of Education [1]. This rapid development of the market and industry is forcing the phenomenon of talent cultivation and reform. Therefore, in the field of talent development, how to change from passive to active, from a talent cultivation method that keeps up with the development of the market to a training method that continuously leads the development of talents has become the current direction of talent cultivation. Zhengzhou, as the central city of national construction and the key hub of the "Belt and Road" initiative, will undertake the mission of exploring and constructing new models and rules for the development of cross-border e-commerce with Chinese characteristics. Aiming at the ecological imbalance of crossborder e-commerce talent cultivation, this paper proposes more long-term solutions and constructs a diversified, multi-level

Project information: letter from the department (bureau) of the Ministry of Commerce, PRC of China (trade promotion letter [2019] No. 18), and list of key research issues in the comprehensive test area of cross-border ecommerce: 49 research on the training system of diversified and multi-level cross-border e-commerce merchants (Liang Zhao) talent cultivation system, which has reference significance for the development of the nation's talent ecology.

\section{Status of TAlent Demand FOR ZhengZhou CRoss- BORDER E-COMMERCE}

Cross-border e-commerce has the characteristics of both international trade and e-commerce [2]. The core of crossborder e-commerce development is international trade, but with the development of the times, new features have emerged in combination with e-commerce. Therefore, the talents of crossborder e-commerce enterprises in Zhengzhou are mainly students majoring in international trade. The shortage of crossborder e-commerce talents in Zhengzhou is mainly manifested in the following aspects: first, talents with e-commerce strategy; second, e-commerce partners; third, compound talents who not only understand online digital technology but also offline retail practice. The main problems of cross-border ecommerce talents in Zhengzhou are as follows: single species, cross-border employees should have knowledge of ecommerce, international logistics, cross-border marketing, international trade practice, etc. However, the existing crossborder e-commerce employees have the poor comprehensive ability, unable to cope with the rapid development of crossborder e-commerce. The food chain is not perfect, and students in the teaching process are divorced from the practical needs of enterprises, which makes it difficult to cultivate compound talents with practical ability to solve practical problems. Due to the lack of practical operation, the cross-border online store of talents has relatively poor practical operation ability. In the process of training cross-border e-commerce merchants, there is a lack of support and services provided by the government, enterprises, talent market and training institutions. The ecological system is not perfect, talent is not clearly defined, and talent selection standards are relatively rigid, lack of targeted regulatory mechanism.

\section{TAlENT CUltivation FOR ZHENGZHOU CROSS- BORDER E-COMMERCE}

The research group found in the investigation on the training of cross-border e-commerce merchants in Zhengzhou that the main reasons for the problem of training cross-border e-commerce merchants in Zhengzhou were the insufficient attention of all parties to the implementation of training and the unreasonable training mechanism. According to the survey 
things and block chain, so that talents can lead the development of the industry and form a virtuous ecological cycle. enterprise cooperation should be adopted in the cultivation of cross-border e-commerce merchants, rather than separate cultivation of schools or training institutions, which is not conducive to the transformation of talent demand of enterprises. However, in our investigation of the current training model of cross-border e-commerce talents, we did not find a highly inclined model, and then in our further investigation, we found that the current school-enterprise cooperation is more formal and specific The implementation of all aspects of responsibility training, talent assessment, and talent development are not in place, making school-enterprise cooperation a "chicken rib". And in our investigation, we found that more than $60 \%$ of the respondents believe that the training of Zhengzhou crossborder e-commerce businessmen has problems such as incomplete content, insufficient investment, and unreasonable training settings, which are manifested as: disconnected theory and practice, too narrow knowledge, Insufficient innovation, low quality of teachers, insufficient investment of teachers, insufficient input of software and hardware, inadequate arrangements of time and place, etc.

\section{CHARACTERISTICS OF TALENT CULTIVATION FOR CROSS-BORDER E-COMMERCE}

\section{A. The first feature of the talent cultivation ecosystem of cross-border e-commerce is diversity}

Because the cross-border e-commerce model combines the characteristics of two aspects of international trade and ecommerce[3], it has greater complexity. Therefore, it is different from the previous requirements of foreign trade and ecommerce, and it requires more diverse capabilities. it is not only to have experience in foreign trade, professional knowledge and language communication and translation ability, also has the capability of domestic and international market demand analysis, data, information and processing power, overseas consumers' information analysis ability, cross-border commodity market sensitivity and external communication and negotiation ability, tolerant, open mind, strong desire for knowledge and innovation spirit, etc.

\section{B. The second feature of the talent cultivation ecosystem for cross-border e-commerce is multi-level}

Since cross-border e-commerce involves diverse demand for capabilities, it is very important for targeted talent cultivation to clarify the hierarchical demand of talents for various capabilities. For example, as managers, they have higher requirements for macro-control ability, but lower requirements on professional depth, while professionals are just the opposite.

\section{The third feature of the talent cultivation ecosystem for cross-border e-commerce is forward-looking change.}

Due to the rapid development of cross-border e-commerce, in the process of talent cultivation, we should constantly combine the new changes in the development of cross-border e-commerce and integrate modern majors and disciplines[4], such as Internet finance, artificial intelligence, Internet of

\section{CONSTRUCTION OF TALENT CULTIVATION ECOSYSTEM FOR CROSS-BORDER E-COMMERCE}

In the process of building an ecosystem for cross-border ecommerce merchants, colleges and universities need to establish market-driven, innovation-oriented training goals and take the characteristics of the cross-border e-commerce talent cultivation ecosystem as the mainline, and the cross-border ecommerce talents' actual situation as the auxiliary line. In the process of building an ecosystem for cross-border e-commerce merchants, it is necessary to establish training goals that are market-driven and innovation-centric. This chapter takes the characteristics of the cross-border e-commerce talent cultivation ecosystem as the mainline, and supplements the actual work situation of cross-border e-commerce merchants with the auxiliary line. Based on three aspects of construction, it analyzes the ecological crisis that exists only for cross-border e-commerce merchants, and provides suggestions for improving the ecological crisis of cross-border e-commerce based on the consideration of talent needs, talent ecology, and talent cultivation, and attempts to build a diverse The multilayered cross-border talent cultivation system to provide ideas (as shown in figure 1 below).

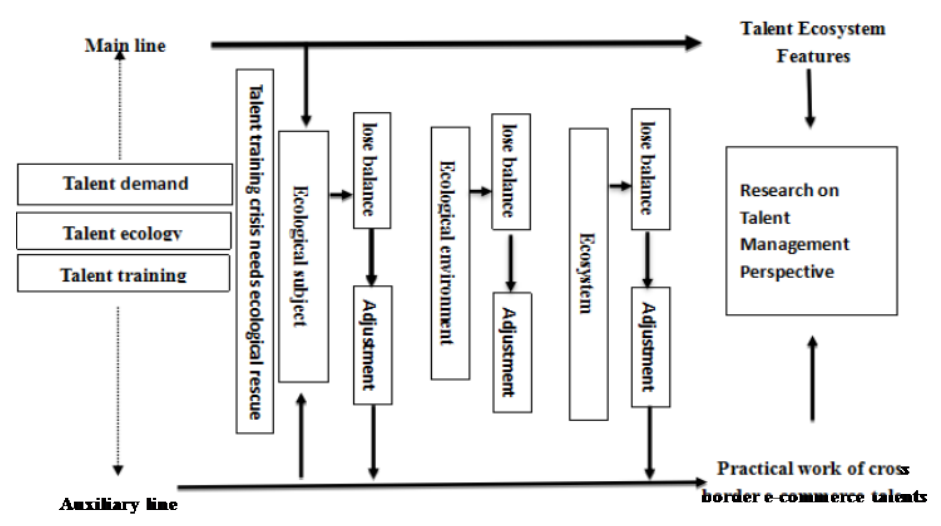

Fig. 1. Construction path of cultivating ecology for a cross-border ecommerce merchant

\section{A. In terms of the ecological subject of the cross-border e- commerce talent ecosystem}

In ecology, the ecological subject mainly refers to the living organism. In the ecosystem for the training of cross-border ecommerce talents, the ecological subject is the cross-border ecommerce talents. From the perspective of current cross-border e-commerce talents[5], the main problems are an insufficient investment in teaching resources, delayed training of talents, irrational curriculum setting, low professional teachers' teaching level, especially the lack of core talents in disciplines, etc. The rescue path of the above practical problems is discussed. 


\section{B. In terms of the talent ecological environment of cross- border e-commerce}

The current problems in the ecological environment of cross-border e-commerce merchants are mainly: the implementation of cross-border e-commerce merchant policies caused by utilitarian education is inadequate, the school's professional talent cultivation mechanism is not perfect, and enterprises do not play a synergistic role, and lack sufficient social support. The environment is not coordinated. We need to establish a cooperative mechanism for the four chariots of government, school, enterprise and society to enhance the cultivation of the ecological environment for cross-border ecommerce merchants.

1) Giving full play to the Government's Guiding Role to create a good Policy Environment

Local governments should formulate comprehensive policies for talent cultivation, strengthen administrative guidance, and provide comprehensive support for cross-border e-commerce talents from a macro perspective. First of all, in terms of financial support, develop a long-term talent cultivation mechanism, and develop preferential policies on finance, taxation, and loans for the training of cross-border ecommerce merchants. Reward cross-border e-commerce companies that have made outstanding contributions. Cultivation of enthusiasm. Secondly, in the face of corporate development, the government must actively build a comprehensive cross-border e-commerce talent exchange platform, continue to develop excellent e-commerce projects, and organize various forms of e-commerce activities to allow organic integration of enterprise development and talent cultivation. Form a good environment for government and enterprises. Finally, the government can actively learn from the development experience of other regions, improve the level of cross-border e-commerce education, promote the reform of cross-border e-commerce teaching system, and form a good political and school environment.

2) Giving full play to the main role of universities to create a good campus ecological environment

As an important place for cultivating high-quality talents, universities need to establish a comprehensive cross-border ecommerce talent cultivation system in light of the current state of cross-border e-commerce development, so that universities can change from a talent "factory" to a talent "cradle" to create a good campus ecological environment. First of all, it is necessary to clarify the goals of future talent cultivation. The setting of future talent cultivation goals should not be orderoriented but "baton". Secondly, the talent cultivation plan should not be a fixed-line plan training in an assembly line, but a "market attack plan" with continuous improvement and multiple participation. Finally, there is the "evaluation mechanism" for talents. Talent evaluation should not be a single-dimensional school's academic assessment, but a comprehensive assessment of the capabilities of all parties.

3) Giving full play to the synergy of enterprises to form a benign school-enterprise cooperation environment

Enterprises should change the concept of talent cultivation according to the current status of the development of the crossborder e-commerce industry, make their own talent planning, 
concretely integrate talent strategies into school-enterprise cooperation, and combine their specific talent needs with school-enterprise cooperation. Matching, while reducing their own talent cultivation costs, build a perfect internship platform for the training of cross-border e-commerce talents, achieve the goal of talent cultivation, and form a healthy school-enterprise cooperation environment.

4) Giving full play to the role of social promotion to improve the ecological deficiencies in all aspects

The society is the main position of talents. Social organizations need to do a good job in cross-border ecommerce publicity[8], further increase the understanding of cross-border e-commerce industry in all sectors of society, continuously absorb more social forces and social capital, and build more comprehensive e-commerce. Cultivation system, through strengthening the construction of a diversified investment model for cross-border e-commerce education, continuously optimizing social resources, strengthening social training, establishing a more professional and perfect crossborder e-commerce training network, and forming a training pattern of participation and a common concern for all people.

\section{In terms of the talent ecological environment of cross- border e-commerce}

As far as the entire cross-border e-commerce talent ecosystem is concerned, he relies on the constant exchange of material, energy and information between the main body of talents and the outside world to maintain the ecological balance, which is embodied in the exchange of talents, knowledge and information. The external environment provides various information to the cross-border e-commerce system, and the cross-border e-commerce system transmits talents, knowledge, and scientific research results to the outside world. Therefore, we can manage the flow of talents, knowledge, and information to better cultivate cross-border e-commerce talents, thereby maintaining the balance of the ecosystem.

\section{1) Managing the flow of talents well}

The flow of talents is the premise of the development of talents, so only by doing a good job in the flow of talents, can we better carry out the work of talent cultivation and development. First of all, in order to do a good job in the flow management of cross-border e-commerce, managers need to respect the freedom of talents[9], respect knowledge and talents, adhere to the concept of serving talents, provide good working conditions, living conditions and living conditions for crossborder talents, increase humanistic care and retain talents. Second, the administrative department of the flow needs to adopt the rigid and flexible management style, effectively break the barriers to cross-border mobility output talent, in the end, all involved departments need to constantly optimize the existing cross-border mobility program, break through the barriers of traditional talent flow, guarantee of men and realize a virtuous cycle to develop talent.
2) Strengthening the management of knowledge flow and information transfer

Cross-border electricity knowledge information transfer should be based on the forefront of academic research, analysis and understanding of the current the latest trends of the discipline and progress, and will be the forefront of knowledge, theory of information transmission in cross-border electricity traders to ecological system[10], promotes the communication of knowledge in cross-border electricity business, realize the sharing of information, talent ecological common development and progress. Therefore, knowledge and information are the driving force for the overall cultivation and development of cross-border e-commerce talent ecology. How the government, schools, enterprises and society participate in and manage the benign flow of knowledge and information is the key to the benign development of cross-border e-commerce talent ecosystem.

\section{SUMMARY}

The construction of a cross-border e-commerce talent cultivation ecosystem is a systematic project. Therefore, the government, schools, enterprises, and society need to actively integrate internal and external forces and optimize existing talent cultivation resources in accordance with the current state of development of the cross-border e-commerce industry and its own situation, guided by market demand and national policies. As a result, China optimizes the cultivation of talents through systematic optimization, cultivates more excellent cross-border e-commerce talents for the society, and promotes the current development of cross-border e-commerce.

\section{REFERENCES}

[1] Zeng Zhao. On the teaching reform of cross-border e-commerce courses under the background of "One Belt And One Road". [J]. Road to success, 2019(28): 11-12. (In Chinese)

[2] Wenjing Yang and Hui. Wang, Research on the reform of international trade talents training in the era of cross-border e-commerce. [J]. Modern marketing (business edition), 2019(12): 10. (In Chinese)

[3] Shuifeng Hong and Yongliang Bai. Research on the training mode of cross-border e-commerce innovation and entrepreneurship talents. [J]. Chinese business theory,2019(21): 243-244 (In Chinese)

[4] Liangqing Xia. Exploring the training mode of cross-border e-commerce merchants. [J]. Economic and trade practice, 2018(24): 191. (In Chinese)

[5] Xiaojing Xu. Construction of "production-teaching integration" ecosphere in higher vocational colleges. [J]. Education and occupation, 2018(12): 51-54. (In Chinese)

[6] Xufang li. Curriculum research in talent cultivation for cross-border ecommerce. [J]. Journal of Wuhan ship vocational and technical college, 2018, 17(04): 87-90. (In Chinese)

[7] Xiaoling Chai. School-enterprise cooperation to build a long-term mechanism for cross-border e-commerce business training. [J]. Think tank era, 2019(44): 99-102. (In Chinese)

[8] Xiaojing Xu. Construction of "production-teaching integration" ecosphere in higher vocational colleges. [J]. Education and occupation, 2018(12): 51-54. (In Chinese)

[9] Guichao Jin, Yufeng Huang, Zuohe Liu. Study on the training mode of cross-border e-commerce in Hangzhou based on school-governmententerprise cooperation. [J]. E-commerce, 2016(10): 73-75. (In Chinese)

[10] LUNDVALL B. National systems of innovation: towards a theory of innovation and interactive learning. [J]. London: Anthem Press, 2010 